\title{
Fragments of Azerbaijan-Russian literary relations: On Sergei Yesenin's Baku visits
}

\author{
Isaxan Isaxanli \\ Khazar University, Azerbaijan \\ Institute of Literature named after Nizami, NASA, Azerbaijan
}

\section{Introduction}

A survey of Azerbaijan-Russian literary relations and their systematic study through the processes of development are issues with special significance and impact on the history of literature in Russia and Azerbaijan as well as in the postSoviet area.The popular Russian poet Sergei Yesenin's creative activities have always attracted special interest for their influence on the development of Azerbaijani -Russian literary relations, and for this reason, they have already been the subject of a great deal of research.

The Russian poet Sergei Yesenin (Russian: Сергей Александрович Есенин) was born in the Konstantinovo village of Ryazan province of Russia on October 3, 1985. After completing a four-year village school, he attended teachers' school in Spas-Klepikovo, situated in the neighbouring city. Yesenin completed that school in 1912, but by that time he had already begun to write his first poems of those years. Soon after having left this school in 1912, Yesenin moved to Moscow. He lived there for a while to improve his education and become closer to the literary world; for that purpose, he entered Shanyavskiy University (free public higher education institution). However, the financial difficulties he faced forced him to interrupt his education. By that time he had regularly been writing poems and sending them to various magazines for publication.

In 1915, Yesenin moved to St. Petersburg, and the life of that city played a special role in his recognition as a poet. Here he was acquainted with well-known poets of the time as A.Blok, S.Gorodetskiy and N.Klyuyev. Here the young poet Yesenin became more involved in the literary world of the time, became a regular participant of literary nights, and earned notable popularity in a short time under these greats' blessing and benefaction.

Between September 1924 and September 1925, Yesenin visited Baku 3 times with breaks in between. In this period, the poet who swooned over Iran with body and soul and considered a trip to Iran a matter of "to be or not to be?" was reaching the 
highest peaks of his poetic activity under the influence of such dreams. During his last visit to Baku (28 July - 3 September 1925), he completed his "Iranian songs" series, which is considered one of the most beautiful samples of his writing and which won him great popularity as a lyric poet. It is quite reasonable that literary critics call this sojourn to Baku the "golden days" in his activities, while comparing these days with "Boldino fall" in Pushkin's activities.

Yesenin committed suicide by hanging himself in the Anqleter Hotel in Leningrad (now St. Petersburg) on the night of December 27-28, while he was only 30 years old.

Sergei Yesenin remains one of the least studied poets in Russia despite the fact that he is among those most read (Yushin, 1969, 9). While this opinion is attributed to the whole literary activity of Yesenin, it would be incorrect to apply it to hisseparate Baku period. Many Russian researchers have studied Yesenin's activities in depth, but their Azerbaijani colleagues have done more comprehensive study of his Baku visit. However, this absolutely does not mean that the studies referring to Yesenin's Baku activities are exhaustive, precise and without any obscurity. Though some 95 years have passed since his first trip to Azerbaijan, research is continuously performed on this issue, and new monographs and publications about Yesenin's activities are still emerging.Moreover, starting from the 1920s, his poems began to be translated into Azerbaijani language, which is still being done by translators today. There are some poems written by Yesenin which have translated by twelve or fifteen different translators.

A wealth of information about Yesenin's Baku life is available in the memories of P.Chagin (Chagin, 1986), who was his closest friend as well as editor-in-chief of "Bak.rabochiy" newspaper, M.Chagina (Chagina, 1980),V.Boldovkin (Boldovkin, 2003),V.Manuylov(Manuylov, 1986),V.Shveytser (Shveytser, 1964; 1966),L.Faynshteyn(Faynshteyn, 1926) and of some other authors. These memories testify that during the period of more than 4 months while Yesenin visited Baku, he was always surrounded by a Russian intellectuals and men of arts. It is also interesting to know whether there were Azerbaijani intellectuals, poets and writers among his contacts.

\section{The socio-political scene of the period of Yesenin's Baku visits}

In his article "Has Yesenin ever been to Azerbaijan?"Yashar Guluzadeh, (Guluzadeh, 1988) attempts to explain why Yesenin did not get in contact or meet with Azerbaijani writers or poets while he visited Baku. He questions: "Why,even 
once, didn't Yesenin meet any Azerbaijani creative intellectual or get acquainted with any local person during his several visits to Baku? "How could it be that Azerbaijani writers such as N.Vazirov, A.Hagverdiyev, S.S.Akhundov, C.Mammad-guluzadeh, H.Javid, U.Hajibayov, A.Javad, J.Jabbarl, A.Shaiq and others who had a great deal of interest in Russian culture and literature did not even try to meet him?'(Guluzadeh, 1988, 32).

The author tries to shed light on this question. While analyzing the socio-political scene of that period, the researcher summarizes it as follows: "Azerbaijan had lost its independence by the time of the Bolshevik invasion. Naturally, intellectuals had a hostile attitude towards the new power... Bolsheviks destroyed their dreams of seeing their motherland as a free and independent state; the invaders suppressed the young Democratic Republic that people actively defended. It is true that mass repressions and shootings of the Azerbaijni intellectuals began a bit later, but the early 1920s were one of the hardest periods in all Azerbaijani history. Eventually, Yesenin visited Baku during those same years. He didn't visit Baku on his own, but by the invitation of those new owners of Azerbaijan the Bolsheviks in power.It is natural that Azerbaijani intellectuals would view him accordingly. We consider thats ituationtobe the main factor behind the fact that Yesenin did not hold any meetings with local poets"(Guluzadeh, 1988, 33).

It seems that those same Azerbaijani intellectuals were responsible for not meeting Yesenin. Though the analyses of the researcher seem sufficiently logical froma socio-political standpoint, it is quite unbelievable that all local intellectuals, poets and writers could make a unanimous decision not to meet Yesenin. Moreover, if we also consider the certain level of increased interest ofAzerbaijani poets and writers towards Russian poets, writers, other popular people such as M.Qorki, V.İvanov, V.Khlebnikov, S.Qorodetski, and V.Mayakovski, who were the contemporary figures of that time and the following years, then it is quite difficult to validate the aforementioned reason to neglect a meeting with Yesenin. On the other hand, when Yesenin came to Baku, he was not an ordinary, but a completely famous poet. He had such a popularity that, despite his presence in Baku "by the invitation of Bolsheviks in power", he maintained quite poor relationships with the leadership; he did not even stop himself from criticizing that power and the realities of the times.His Baku visits were not solely organized by his friends. In his poem "Stansi"(dedicated to P.I.Chagin) the poet notesthat,"as he could not do anything with the police, he left Moscow for a long period to escape them" (Yesenin, 1983, 357).

In such a situation, one can hardly believe that the local artists, poets and writers did not seek to benefit from this visitby exchanging ideas while Yesenin chose 
Baku as a refuge during his hard times. Moreover, his interest in Eastern poetry and the great poets of the East would also be interesting for Azerbaijani poets and writers in a sense. Therefore, it is difficult to believe that Azerbaijani poets and writers neglected to meet him.

Thus, it seems more logical to blame the lack of meetings on Yesenin's friends who were serving as governmental officials, who in our opinion also did their best to isolate him from such meetings. It is likely that one of the reasons why Yesenin stayed in the cottage of his friend P.I.Chagin, who served as a government official, during his Baku sojourn is that this was his friends' "isolation plan".

Then what was the reason for isolating Yesenin from meetings with Azerbaijani poets, writers and intellectuals, and for whom was this isolation plan necessary? What was the expected "threat"of such meetings? These types of questions are inevitable.

In the end of the $19^{\text {th }}$ and at the beginning of the $20^{\text {th }}$ century, a wide national renaissance process began in Azerbaijan. Almost all Azerbaijani intellectuals, poets and writers whose names were mentioned in article by Y.Guluzadeh above, as well as Ahmad Javad, Abdulla Shaig, Jafar Jabbarli, Huseyn Javid and others, were vocal supporters of the idea of Azerbaijan "turkism" or "turanism" (propagating Turkish unity) in poetry during 1918-1920. A. Ildirim, as a messenger of national ideas, was forced to leave the country in the 20s and 30s; he first lodged as a migrant in Iran and then moved to Turkey.The establishment of Azerbaijan Democratic Republic (ADR) in 1918 was the fruit of faithfulness to these ideals. Even when Azerbaijan was occupied by Russiafor its further inclusion into the USSR, people's thoughts were not changed over that short period because this was a political revolution; instead, their national ideals of "turkism" and "turanism" took on new character. Yesenin was also not one to praise Soviet power in general. The fact that he was not allowed to go to Iran shows that he was distrusted by the government. Under those circumstances, Yesenin's meetings with Azerbaijani intellectuals, poets and writers to freely exchange thoughts with them might have sown the seeds of serious objection against Soviet power in Yesenin's mind and thoughts; it also may have cool edhis relations with the government, possibly leading him astray from Soviet ideology. However, the government tried not to lose such famous poets as Yesenin who was highly cherished by the people; on the contrary, wherever possible, the government wished to win them over and solicit their praise of the current government. The author believes that this ideology was the main reason why the government kept Yesenin isolated from Azerbaijani intellectuals, poets and writers, and tried to keep him within an all-Russian environment while in Baku. 
After submitting this article to the editorial board of this journal, I received a recommendation from the editor-in-chief.Along with his opinion and recommendations on several issues reflected in the article, Professor Hamlet Isaxanli touched upon some issues realted to Yesenin's relations with Azerbaijani intellectuals, poets and writers when he visited Baku. He also explained the factors restraining Yesenin from such meetings as follows:

1. The above mentioned and unmentioned Azerbaijani poets of the time were not properly aquianted with Yesenin's poetry, and for that reason, theydid not express a special interest towards him.

2. Yesenin, in his turn, did not properly know Azerbijani poets and writers henceforth he did not have a special interest in meeting them.

3. As a poet, Yesenin was primarily interested not namely in Azerbaijan, but in Iran; consequently, he was not interested in Azerbaijani poets, but rather in Eastern classics as Sadi, Hafiz, Khayyam and others.

Whatever the reason, it is quite surprising that S.Yesenin did not meet any Azeri intellectual, poet or writer at all during his Baku visit. For comparison, there area huge number of materials available to researchers who want to write about Yesenin's Georgian visits in the form of memoirs. We encounter sufficientl and interesting memories and notes in the works of Georgian writers and poets such as T.Y.Tabidze, N.A.Tabidze, Q.N.Leonidze, S.İ.Chikovani, Sh.N.Apkhaidze, V.İ.Qaprindashvili, S.İ.Shanshiashvili, T.Q.Yashvili and N.İ.Qudiashvili related to Yesenin's visit to Georgia (Bebutov, 1968, 1986 ; Leonidze, 1986; Tabidze T.Y., 1986; Tabidze N.A., 1986). In the writings of T.Y.Tabidze we find very interesting information about Yesenin's will to engage in establishing close literary-cultural relations between the two nations of Georgia and Russia, as well as his intention to translate of Georgian poetry (Tabidze, T.Y., 1986, 194).

It would be interesting to remember one of these cases. There is an anectote in the memories of V.I.Boldovkin about Yesenin. On May 22, 1925, Boldovkin returned to Baku from Tehran and was met by Yesenin; they spent 2 or 3 days together and on May 25 they travelled to Moscow by train. On one of those days Yesenin talked to Boldovkin about his relations with Boldovkin's parents and about their frequent visits to him while he was in the hospital. Boldovkin notes that Yesenin addressed his father not as Ivan Ivanovich as before, but in the Azerbaijani language as Ivanzade (Boldovkin, 2003, 87). This small episode which has gone completely unnoted until this writig shows Yesenin's interest in the Azerbaijan language (Although Ivanzade is pure Iranian form of Surname, passed into Azerbaijani Ed.). 


\section{Episodic meetings}

We have memoirs about Yesenin of only two Azerbaijanis who were his contemporaries; these are Ramazan Khalilov, who worked as an"AzerTAC" reporter and as a freelance correspondent of the "Bak.rabochiy" newspaper, and Gulam Mammadli, prominent journalist and annalist. In the writings published in one of Baku's newspapers on the eve of S.Yesenin's $100^{\text {th }}$ anniversary, R.Khalilov describes his meeting with the poet in April and May of 1925 (Khalilov, 1995).This article is almost entirely devoted to a banquet party where the author took part together with Yesenin, andthereare no other facts presented in this article about Yesenin's Baku life.

Though the memories by G.Mammadli were written in the 70 s, they were not published until 2016. In these memories which existed as a handwritten manuscript for long years, the author briefly speaks about his short meeting with Yesenin.Hegives brief information about the poet's frequent arrival to the editorial office of "Bakurabochiy" newspaper in a drunken state when he was in Baku in 1924-25 so he could readhisnewly published poems. The author also mentions Yesenin reading his materials in the complete set of pages of the newspaper (Mammadli, 2016, 85-86).

There is also information written by Svetlana Vladimirovna Kurochkina, granddaughter of popular opera singer and F.I.Shalyapin's student Fatma Mukhtarova about Yesenin's meeting with Fatma Mukhtarovain May 1925 (Kurochkina, 2004, 67-68).S.Kurochkina put forth a new theory related to this: F.Mukhtarova may have played a role in shaping Yesenin's impressions of Baku while he was creating his "Iranian songs" series (Kurochkina, 2004, 68).

\section{Yesenin and famous Azeri singer JabbarGaryaghdioglu}

While speaking about Yesenin's Baku meetings, his meeting with the famous Azeri singer Jabbar Garyaghdioglu (Azerbaijani: Cabbar Qaryağdıŏlu) deserves special mention.

Jabbar Garyaghdioglu was born on March 31, 1861 in Shusha, Garabagh (Karabakh), which is considered a cradle of Azerbaijani music. Besides being a proficient connoisseur of mugham art, Jabbar Garyaghdioglu was also an innovator of singing who brought many novelties to this sphere of art; particularly,he collected about 300 Azerbaijan folk music samples and gave them to the Music Conservatory.The Azeri musician F.Shushunksiy, who systematically investigated 
the history of singing in Azerbaijan,called Jabbar Garyaghdioglu "a live encyclopaedia of musical folklore", "the founder of the Azerbaijani vocal school" and "The thinking brain of folklore music". Jabbar Garyaghdioglu died in Baku on April 20, 1944 when he was 83 years old.

The earliest information available about Yesenin's meeting with Jabbar Garyaghdioglu isin an article by A.K.Voronskiy which was published in 1926 (Voronski, 1926, 135-136).The next is from nearly 40 years later, in 1965, whenL.Polonskiyde scribed some moments of the meeting in his article called "Two songsters" (Polonski, 1965). Later, in "Books and years" (Polonski., Portnov, 1974) which he co-authored with V. Portnov, L.Polonskiy put forward the idea that it wasYesenin at that meeting who for the first time called Jabbar Garyaghdioglu "the prophet of Eastern song".

In his book "Jabbar Garyaghdioglu" published in 1987, Azerbaijani musician Firidun Shushinskiy writes that the meeting of Yesenin and Jabbar Garyaghdioglu took place at a banquet held in honour of Yesenin (Shushinski, 1987, 97-98).

It is necessary to note that the banquet took place not in honor of Yesenin, as Shushinskiy claimed, but in honour of high-ranking official M.V.Frunze, chairman of the USSR Military Counsel. On April 13, 1925, Frunze came to Baku from Moscow and after staying for several hours in Baku he left for Tbilisi. Then Frunze returned to Baku on April 17 for another two-day stay after which he returned to Moscow on April 19. Voronskiy accompanied Frunze during that visit as a journalist. If we take into account that Voronskiy was a participant of that meeting, it becomes obvious that it was held on April 17 or 18. Evidently, Yesenin was also invited to this celebration. In fact, Jabbar Garyaghdioglu was almost constantly an honorary guest of such high-ranking banquets and meetings of the time.

Another researcher, Zemfira Yusifgizi, the author of the monograph "The prophet of Eastern music"about the life and activities of Jabbar Garyaghdioglu, also writes about the meeting of Yesenin and Jabbar Garyaghdioglu. She put forward a new idea about this meeting: "Sergei Yesenin wrote these words on the "Gramophone recordissued in Warsaw" (emphasis is mine- I.I.): "Jabbar Garyaghdioglu, the prophet of Eastern music" (Yusifgizi, 2008, 54).

Specialists are in complete disagreement about whether Yesenin first used the term "the prophet of Eastern music" about Jabbar Garyaghdioglu at that meeting. As mentioned above, this term was first used in the article by L.Polonskiy in 1965. In the introduction to the article L.Polonskiy wrote that he had heard these thoughts fromV.I. Boldovkin (the younger brother of P.I.Chagin, the editor-in-chief of "Bak.rabochiy" newspaper and Yesenin's friend). As V.I.Boldovkin was not in 
Baku at that time, he did not participate in that meeting. He worked at a diplomatic post office service inthe Embassy of the Former Soviet Union (FSU) to Tehran and visited Baku about a month later, on May 22. He was almost together with Yesenin during his Baku journey. Moreover, they were also together for 2-3 days when Yesenin returned to Baku from Iran on May 22, and then they left for Moscow together on May 25. Therefore, V.I.Boldovkin was sufficiently informed about the events which took place and about the details of meetings with Yesenin. Therefore, it is logical to accept L.Polonski's ideas as true about what he heard from V.I. Boldovkin.

In contrast to this, Zemfira Yusif gizi's idea thatSergei Yesenin inscribed the words "Jabbar Garyaghdioglu is the prophet of Eastern music" on a"Gramophone record issued in Warsaw" (emphasis is mine - I.I.)is not based on a concrete source.The stated record has not been preserved today, and there are no other written sources about this idea. In order to investigate the truth, the author madecontact with Z.Yusifgizi and tried to arrange a meeting with the last-born child of Jabbar Garyaghdioglu, his daughter Shahla Garyaghdi Kurchayli. She is the wife of the Azerbaijani poet Aliagha Kurchayli, who made several translations of Yesenin's poetry. Because of her health conditions, we were only able to speak over the phone.She said: "That gramophone record was in our family and I saw it, then it was kept by Gurban Primov(famous Azerbaijani musician and tar player; member of the famous trio created by Jabbar Garyaghdioglu in 1905 that influenced the development of Azerbaijani music- I.I.). I was a little girl at that time and did not notice what was written on it. Unfortunately, the record with its historical importance is unknown now."

The editor of Zemfira Yusifgizi'sbook "The Prophet of Eastern Music",Prof. SevdaIbrahimova, said that she also saw that record. Ibrahimova is Gurban Primov's granddaughter, and if we take into account that the said record was kept by Gurban Primov, it is natural and convincing that she could have seen it. Since that historical record is not in our hands, we must accept the two women's eyewitness reports of it as substantial sources.

Summarising various ideas about this, we can come to the conclusion that the main reason for conflict among researchers related to this issue is that A.K Voronski made no remark upon the idea that Yesenin first called Jabbar Garyaghdioglu "the prophet of Eastern music" in his article where he gave information about their meeting.Due to the sensitive nature of this issue, researchers became more cautious while addressing this matter and putting forward their own ideas. 
How can we explain the absence of the idea that Yesenin called Jabbar Garyaghdioglu "the prophet of Eastern music" in the above mentioned article of Voronski? We think that the reason is clear. The main subject of investigation in that article is not Jabbar Garyaghdioglu, but Yesenin. Therefore, the author did not mention Yesenin's thoughts about Jabbar Garyaghdioglu in his article, but only wrote Jabbar Garyaghdioglu's words to Yesenin. However, in the article ofL.Polonskiy, the subject of investigation was both persons and the above mentioned meeting in both places was described more comprehensively. Therefore, based on the article of L.Polonksi, we can accept it as fact that Yesenin called Jabbar Garyaghdioglu "the prophet of Eastern music" during their historical meeting. Just taking this into account, Yesenin's name was included in the 2010 edition of the Mugham Encyclopaedia issued in Azerbaijan (Mugham Encyclopaedia, 2008, 202).

Detailed information about the meeting with Jabbar Garyaghdioglu is given in the article named "Two nations' songsters: Sergei Yesenin and Jabbar Garyaghdioglu." The article clarifies some new points(Isaxanli, 2013).

\section{Another meeting with Jabbar Garyaghdioglu}

In his article "Songs of Jabbar Garyaghdi (from the Caucasus meeting of the poet)," S.Koshechkin, a well-known researcher of Yesenin, writes about another meeting of Yesenin with Jabbar Garyaghdioglu.The article appears to be less than concrete; however, it is clear from the context of the article that this meeting took place on September 23, 1924. The author describes this meeting with the younger daughter of Jabbar Garyaghdioglu, Mrs. Shahlakhanum, and adds her comments about memories concerning to the meeting of Yesenin and Jabbar Garyaghdioglu.Though we could not meet Shahlakhanum because of her health problems, it was clear from our talk with her son Mr. Ulfatthat Sergei Koshechkin really did visit their house several times and that Shahlakhanum had spoken with him about Yesenin's meetings with Jabbar Garyaghdioglu. Mr. Ulfatalso visited SergeiKoshechkin's house in Moscow as a family guest. However, given the circumstances, it is difficult to understand some inaccuracies about the meeting of these two people in Sergei Koshechkin's article. We read about this meeting in the article: "The younger daughter of Jabbar Garyaghdioglu tells me that this was a great holiday for her father. But, when I talked to her, half a century had already passed since Sergei Yesenin last visited their house. At that time, she was only seven years old. Did she remember the poet? She remembered him very well". 
"We often had visitors: my father was a very communicative man and he liked dinner parties with his friends," Shahla khanum remembers. "I have read that those who saw Yesenin for the first time mostly paid attention to his golden hair. $\mathrm{He}$ could attract a small girl like me with onlyhis childish, naïve and a little bit mischevious smile."

Shahla khanum opens Yesenin's book, look at his portrait and continues: "He seems younger to me than he is in this photo. I remember: he bent down to me and said some kind words. Then he squatted in front of me and looked into my eyes. Now I think maybe he remembered his daughter. That was probably the case; you know, he loved her and missed her. At that moment, my mother took me and my sister to another room" (Koshechkin, 1994, 188).

It should be mentioned that the youngest daughter of Jabbar Garyaghdioglu,Shahla khanum, was born in 1928, three years after Yesenin's death. However, the author of the article talks about the "The meeting of Yesenin with 7-year-old Shahla".

Let us look at another moment apart from the aforementioned citation: "when I talked to her, half a century had already passed since Sergei Yesenin last visited their house". It is obvious that the author met Shahlakhanum in the middle of 70s when she was 46-47 years old. Koshechkinwrites: "I look at Shahla and try to imagine her like a little girl when Sergei Yesenin looked in the eyes of that sevenyear-old girl. However, this is impossible. The years have done their work: her face now has some wrinkles which once breathed fresh; her hair has become gray; those eyes once gold and sparking with life have now grown pale"(Koshechkin, 1994, 189).As it is seen, this is not a description of a 46-47 year-old woman, but somebody between 70 and 80 years old.

We may conclude from all the above that Sergei Koshechkin did not base his article entitled"Jabbar Garyaghdi songs (from the Caucasus meetings of the poet)" on truth, but rather on his own fantasy.

\section{Sergei Yesenin and Aliagha Vahid: Reality or Myth?}

One of the controversial moments of Sergei Yesenin's Baku visits is related to his meeting with the prominent Azerbaijani poet Aliagha Vahid; this fact is not confirmed yet.

Aliagha Vahid was born in Baku on February 18, 1895. He had a special role in the development of love poetry in Azerbaijan. Aliagha Vahid wrote in an ancient and lyrical poem genre, ghazal. His poetry played an important role in the development 
of Azerbaijani mugham art. Aliagha Vahid died in Baku on September 30, 1965, when he was 70 years old.

Though we do not have any facts, some authors still write about Yesenin meeting with Aliagha Vahid while he visited Baku (Mammadov, 1995; Aslan, 1995; Mahmudova, 2004).

All authors who wrote about the meeting between Yesenin and AliaghaVahid expressed their views based on Huseyn Najafov's documentary "May in Balakhani" (Najafov, 1986). In this narrative, Yesenin and Vahid were acquainted on September 23, 1924 and after 2 days, i.e. on September 25, they went to the Shaghan village near Mardakan to take part in a"Fizuli" poetic conference. We become acquainted with some places, names and events in this narrative which is based on the artistic fantasy of Huseyn Najafov. Some events and scenes are described interestingly and skillfully in this narrative which masterfully weaves the story of how Yesenin and Aliagha Vahid wine and dine around the same table while talking about poetry, poets, the participants' attitude toward other guests and some events (Najafov, 1986, 102-105,137-142).

The painter R.Mehdiyev who described the meeting of the two poets at the "Fizuli" banquet also used this documentary's information while creating his "Aliagha Vahid and Yesenin" scene. It should also be mentioned that these works by R.Mehdiyev are kept in the Memorial Home Museum of Sergei Yesenin in Mardakana long with other works that are dedicated to Yesenin.

Lay people also entertain their own thoughts about the meeting that took place between Yesenin and Aliagha Vahid. According to the information provided by Dr. Kamala Zeynalova, Nizami National Literature Museum staff member, Yesenin managed to provide a house for AliaghaVahid with the help of his friend, P.I.Chagin.

Despite our best efforts to find historical documents and actual materials about these meetings that were claimed above, we were unable to find any primary source papers to confirm the meetings.

\section{Conclusion}

We tried to describe the general scene of Yesenin's meetings while he visited Baku, considering even the smallest significant events and minor moments while pursuing the objective reality, historical facts and the general realities of the day. 
Thus, based on the above mentioned analyses and judgements that we have conducted, we may draw the conclusion thatthe socio-political scene and literary environment of the time when Yesenin lived in Baku negatively affected his chances to meet Azerbaijani poets, writers and intellecutals. As a result, the Russian poet lived in a Russian environment and was surrounded with Russian intellectuals in Baku.

The analyses conducted in this article show that Yesenin and Jabbar Garyaghdioglu did not meet several times as some authors write, but only once, and this sole meeting happened by chance in April of 1925. S.Koshechkin's article "Jabbar Garyaghdi's songs (from the Caucasus meetings of the poet)" talking about a meeting between Yesenin and Jabbar Garyaghdioglu on September 23, 1924 is not based on fact or historical reality, but rather on the auhtor's fantasy. This type of peculiar rumour not only fails to enrich the body of knowledge about Yesenin's Baku meetings, but also possibly changes the related facts and events into myths. One should be extremely sensitive, cautious and attentive and should not dissiminate suspicious views while speaking about contacts and relations of prominent people like S.Yesenin and J.Garyaghdioglu.

As for the meeting of Yesenin with AliaghaVahid, despite the appeal of the discussions above and the rumors in circulation, the truth is that there are no sources pointing definitively to a meeting of these two great persons in the archive materials or in any memoires of his successors, in the records of Yesenin himself, or in the writings of Aliagha Vahid. We must not base historical studies on the documentary "May in Balakhani" by Huseyn Najafov; many authors base their writings on this narrative, but it must not be confused as a real fact.

\section{References and notes:}

Aslan K. (1995). The poet praising beauty. "Vishka" newspaper, November, 17

Bebutov G.V. (1968). About Sergei Yesenin. Four sketches // "Lit.Qruziya" magazine, No.10, pp.90-94

Bebutov G.V. (1986). Sergei Yesenin in Georgia. "Friends in taste and measure..." Tbilisi, "Mirani”, pp.13-99

Boldovkin V. (2003). He is nearest and dearest for all of us // "Slovo". Russian artistic literature and social idea magazine. M., No.2, March-April, pp.84-99

Chagin P.İ. (1986). Sergei Yesenin in Baku // S.A.Yesenin in the memories of his successors. In 2 volumes, $2^{\text {nd }}$ volume M.," Belles-lettres", pp.160-164

Chagina M.A. (1980). Meetings with Yesenin. "Soviet culture" newspaper, October, 7

Faynshteyn L. (1926). Sergei Yesenin in Baku // S.A.Yesenin. Memories. M.- L., pp.116-124 
Guluzadeh Y.M. (1998). Has Yesenin ever been to Azerbaijan? // Actual problems of learning the humanities. Thesis of the Republic higher school's scientific conference lectures and news. 27-28 January 1998. Baku, "Translator", pp.32-34

Isaxanlı İ. (2013). Two national singers: Sergei Yesenin and JabbarGaryaghdioglu // Collection of materials of works of the international scientific conference devoted to the $117^{\text {th }}$ anniversary of S.A.Yesenin's birth and Russian history. Moscow-Konstantinovo-Ryazan, pp.407-414

Khalilov R. (1995). Worthy is known from a distance. "Gunay" newspaper, October, 7

Koshechkin S. (1994). Songs of JabbarGaryaghdioglu. From the Caucasus meetings of the poet // Oh, Russia, open your wings. Yesenin collection. $1^{\text {stedition. }}$ M., "Nasledie", pp.186-192

Kurochkina S. (2004). Narrative about actress. Baku, "Yurd", p.144

Leonizde Q.N. (1986). I see this man // S.A.Yesenin in the memories of his successors. In 2 volumes, $2^{\text {nd }}$ volume. M., "Belles-lettres", pp.200-207

Mahmudova K. (2004). Azerbaijani poet AliaghaVahid and Sergei Yesenin // Yesenin and 20-21 $1^{\text {st }}$ centuries Russian poetry. Traditions and innovations. Materials of the internationsl scientific conference. Moscow- KonstantinovoRyazan, pp.175-179

Mammadli Q. (2016). Pages from life paper (1897-1977). Memories. Meetings. Observations. Baku, "Education", $184 \mathrm{p}$

MammadovS.A. (1995). Again, about Sergei Yesenin's visit to Baku // Thematic collection of the scientific article devoted to the $100^{\text {th }}$ anniversary of Sergei Yesenin. Baku, "Translator", p.10

Manuylov V.A. (1986). About Sergei Yesenin // S.A.Yesenin in the memories of his successors. 2 volumes, $2^{\text {nd }}$ volume. M., "Belles-lettres", pp.165-190

MughamEncyclopaedia. (2008). Heydar Aliyev Fund. Bak1, 215 p.

Najafov G. (1986). «May in Balakhani». Documentary artistic narrative. Baku, "Ganjlik".

Polonski L. (1965). Two singers. "Bak. raboçi” newspaper, October, 3

Polonski L., Portnov V. (1974). Two singers // Polonski L., Portnov V. Books and years. Pages of Russian and Azerbaijani cultural relations. Baku, "Azqosizdat", pp.41-45

Shushinski F. (1987). JabbarGaryaghdioglu. Baku, "Light", 126 p.

Shveyser V. (1964). Sketches for portraits // Melody. "Moscow" magazine, No.2, pp. $183-187$

Shveyser V. (1966). Melody. Dialogue with the past. "Art" publishing house, Moscow, pp.57-71

Tabidze N.A. (1986). From the Memory book // S.A.Yesenin in the memories of his successors. In 2 volumes, $2^{\text {nd }}$ volume. M., "Belles-lettres", pp.195-199

Tabidze T.Y. (1986). S.Yesenin in Georgia // S.A.Yesenin in the memories of his successors. In 2 volumes, $2^{\text {nd }}$ volume. M., "Belles-lettres”, pp.191-194 
Voronski A.K. (1926). "About Taking aside”, Literary notes. Artel of writers. "Kruq", pp.135-145

Yesenin S.A. (1983). Collection of works in 3 volumes, volume 1. M., "Pravda" publishing house, $432 \mathrm{p}$.

Yushin P.F. (1969). Sergei Yesenin. Revolution of idea-activity. Moscow (hereinafter "M."), Publishing House of "Moscow University".

Yusifgızı Z. (2008). The prophet of Eastern music. Baku, "East-West”, 159 p.

\title{
Summary
}

\section{Fragments of Azerbaijan-Russian literary relations: On Sergei Yesenin'sBaku visits}

\author{
Isaxan Isaxanli \\ Khazar University, Azerbaijan \\ Institute of Literature named after Nizami, NASA, Azerbaijan
}

This article is devoted to Sergei Yesenin's meetings while he visited Baku in 1924-1925; it explores his relations with Azerbaijani intellectuals, poets and writers. Here we also carry out analysis on the socio-political scene of the period during Yesenin's sojourn to Baku. The article clarifies points related to Yesenin's meeting with famous singer of Azerbaijan, JabbarGaryaghdioglu, as well as with popular Azerbaijani poet, AliaghaVahid, the events of which have been the subject of debate.Although many researchers consider the latter meeting to be a fact, the article emphasizes that there is no historical document to prove it. The article also contains information about Yesenin's intermittent meetings with some famous Azerbaijani people which are still uncertain.

Keywords: Sergei Yesenin, Azerbaijan-Russian literary relations, Yesenin and Azerbaijan, Sergei Yesenin's Baku meetings 